\title{
Genetic analyses of days to calving and their relationships with other traits in a Canchim cattle herd
}

\author{
Talita Buttarello Mucari ${ }^{1,2}$, Maurício Mello de Alencar ${ }^{3}$, Pedro Franklin Barbosa ${ }^{3}$ \\ and Rogério Taveira Barbosa ${ }^{3}$ \\ ${ }^{1}$ Universidade Federal de São Carlos, São Carlos, SP, Brazil. \\ ${ }^{2}$ Universidade do Estado de Mato Grosso, Nova Xavantina, MT, Brazil. \\ ${ }^{3}$ Embrapa Pecuária Sudeste, São Carlos, SP, Brazil.
}

\begin{abstract}
Heritabilities and genetic correlations in a Canchim beef cattle herd were estimated using data on the following traits: male scrotal circumference at twelve months (SC12); days to first calving (DFC) for heifers; days to calving (DC) for cows; male and female weight (W) at twelve months (W12); heifer weight at the start of the first breeding season (WFBS) and at first calving (WFC); and cow weight at the start of the breeding season (WBS) and at calving (WC). Analyses of the DFC and DC traits were carried out excluding and including penalized (DFC $C_{P}$ and $\left.D_{P}\right)$ non-calving females. The restricted maximum likelihood method was used, applying one-trait models for the DFC and DC analyses and two-trait models for analyses of DFC and DC combined with the other traits studied. Statistical models included fixed and additive direct random effects for all traits, maternal permanent environmental random effect for

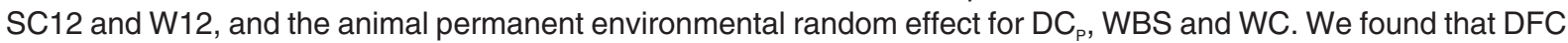
and DC values can be improved by selecting for an increase in the SC12. Genetic correlations between DFC and W12 and between DC and W12 indicated that selection for increased W12 may increase DFC but does not produce significantly correlated responses in DC. Associations of the other body weight traits with DC and DFC suggest that heavier females experience lower reproductive performance.
\end{abstract}

Key words: beef cattle, body weight, days to calving, days to first calving, genetic correlation, heritability, scrotal circumference.

Received: September 18, 2006; Accepted: May 17, 2007.

\section{Introduction}

In Brazil beef cattle genetic evaluation programs are now taking into account reproductive traits instead of growth traits only (Euclides Filho, 1999). The inclusion of reproductive traits allows breeders to save time by exposing heifers earlier to reproduction and thus reducing the generation interval.

Scrotal circumference (SC) of males and weight at different ages are traits usually used in expected progeny difference indices, and their application has lead to satisfactory gains in growth and reproductive rates (Garnero et al., 2001; Gunski et al., 2001; Pereira et al., 2001).

Bourdon and Brinks (1983) and Bergmann et al. (1998) reported that the calving interval (CI) is subject to more measurement and estimation bias and errors than days to calving (DC). The DC trait has been recommended for

Send correspondence to Talita Buttarello Mucari. Universdade do Estado de Mato Grosso, Av. Brasília 117, Centro, Setor Nova Brasília, 78690-000 Nova Xavantina, MT, Brazil. E-mail: tmucari@ yahoo.com.br. assessing the reproductive performance of females because the DC value predicts the ability of individual dams to conceive early in the breeding season and to calf early in the calving season (Gressler et al., 2000). Furthermore, DC identifies females with the highest fertility and the bulls whose daughters have lower DC values and calve sooner (Pereira et al., 2000). Phenotypic expression of DC is a composite trait, which combines sire effects associated with libido and semen quality, dam effects associated with beginning of the estrus cycle and fertility and calf effects that control the start of parturition (Macneil and Newman, 1994).

Female body weight (W) at the beginning of the breeding season (WBS) and at calving (WC) are other factors affecting herd reproductive performance. According to Randel (1990), the body weight and condition score of the cow at calving are indicators of subsequent reproductive performance because inadequate pre- or post-parturition nutrition in terms of protein and/or energy reduces the first service conception and gestation rates. 
The Canchim (5/8 Bos taurus Charolais $+3 / 8$ Bos indicus Zebu) beef cattle breed has been studied both as a pure breed and in crossbreeding programs, and researchers are studying appropriate selection criteria for this breed to increase herd productivity (Alencar et al., 1981; Alencar and Bugner, 1986; Alencar et al., 1993; Mello et al., 2002). However, despite the previous research, data associating the scrotal circumference of males and female body weight at different points in the reproductive cycle with female reproductive traits are still scarce in this breed. Genetic analyses of the days to first calving (DFC) and DC trait for Canchim females and the relationship of these traits with the scrotal circumference of 12-month males (SC12), male and female 12-month body weight (W12) and the weight of the cow at the start of the breeding season (WBS) and at calving (WC), all of which have not previously been defined for this breed, would help breeders to choose selection criteria and obtain genetic progress in herd productivity. The objective of this study was to estimate heritabilities for the DFC and DC traits and assess their genetic correlation with the SC12, W12, WBS and WC traits in a Brazilian Canchim herd.

\section{Material and Methods}

The data used in this study came from the Canchim herd of Southeast - Embrapa Cattle, an unit of the Brazilian Agricultural Research Corporation (Empresa Brasileira de Pesquisa Agropecuária - Embrapa), located near the town of São Carlos in the Brazilian state of São Paulo. The cattle in the herd were raised on pasture and received a mineral mixture and health care appropriate for the region. The climate of the region is tropical CAw on the Köppen climate classification. The herd was maintained closed since its formation in 1953 until 1999 when new Canchim lines started to be introduced, inbreeding however, was always avoided.

Reproductive management of the females in the herd included different criteria regarding when they were serviced by bulls. Initially, heifers were first serviced when they were about 34 months old but this was reduced over the years and is now about 22 months. Body weight of the heifers at the time of service and breed traits were also taken into account. Furthermore, after calving the cows were initially serviced after weaning but from 1976 onwards all cows were serviced during the breeding season except for those which would calve after the end of the current breeding season. Breeding groups were composed of one bull and about 30 cows but since 1979 artificial insemination was also used. Culling of cows was mainly due to diseases and/or accidents, but in 1977 culling due to low fertility (two consecutive failures) was started.

The DFC and DC data were from 2,105 females born from 1953 to 2001, which participated in breeding seasons from 1957 to 2003 . The breeding seasons had no fixed starting or finishing month and were of variable length. In some years there were two breeding seasons, one in the first and another in the second semester.

The DFC and DC records were calculated from the difference between calving date and the date of the beginning of the breeding season. Another set of data was formed, in which females which did not conceive during the breeding season received a penalty and had their DFC and DC values calculated as 21 (one estrus cycle) plus the highest DFC and DC of its contemporary group (Johnston and Bunter, 1996). The penalized values were generally denominated $\mathrm{DFC}_{\mathrm{P}}$ and $\mathrm{DC}_{\mathrm{P}}$. Two data sets were formed for $\mathrm{DC}$ and $\mathrm{DC}_{\mathrm{P}}$, one for cows only $\left(\mathrm{DC}_{\mathrm{C}}\right.$ and $\left.\mathrm{DC}_{\mathrm{PC}}\right)$ and another for heifers plus cows $\left(\mathrm{DC}_{\mathrm{HC}}\right.$ and $\left.\mathrm{DC}_{\mathrm{PHC}}\right)$.

To analyze DFC we produced a data set containing 1,197 DFC values for first breeding season heifers only. However, to analyze DC we used two data sets, one containing 4,166 DC values for cows only $\left(\mathrm{DC}_{\mathrm{C}}\right)$ and another containing 5,403 DC values for cows and heifers combined $\left(\mathrm{DC}_{\mathrm{HC}}\right)$. When females which did not conceive were added, the number of DFC values increased to 1,840 , while the number of DC values for cows only increased to 6,823 and that for cows plus heifers rose to 8,736.

Male and female body weights were standardized to 365 days based on gain from weaning to yearling (W12), data being available from 1953 to 2004 . Scrotal circumference (SC12) data was available from 1982 to 2004, except between 1990 and 1991. Data on WC and WFC were available from 1977 to 2004, while WBS and WFBS were available for the 1980 to 2003 breeding seasons.

The number of animals and observations for each trait are shown in Table 1. Before the analyses, data referring to twins, abortion, embryo transfer, exhibition animals, supplemented animals, experimental animals and outliers were deleted from the database.

Variance and covariance components and genetic parameters were estimated by the restricted maximum likelihood method using the MTDFREML program (Boldman et al., 1993).

A one-trait animal model was used to estimate the DFC, $\mathrm{DFC}_{\mathrm{P}}, \mathrm{DC}_{\mathrm{C}}, \mathrm{DC}_{\mathrm{HC}}, \mathrm{DC}_{\mathrm{PC}}$ and $\mathrm{DC}_{\mathrm{PHC}}$ heritabilities. For the $\mathrm{DC}$ and $\mathrm{DC}_{\mathrm{P}}$ data the one-trait model included not only additive direct random effects but also fixed effects of contemporary group (breeding season, mating type (natural service or artificial insemination) and service bull), physiological state of the female (first breeding season heifer, cow with or without a calf, and cow which calved during the breeding season) and age of the female at the beginning of the breeding season as a covariate (linear and quadratic effects). This model was applied without animal permanent environmental effects (model 1) and with animal permanent environmental effects (model 2) and the two models compared using the likelihood ratio test (Mood et al., 1974). For analyses of DFC and $\mathrm{DFC}_{P}$ data the model considered only contemporary group fixed effects and additive direct random effects. Previous least squares analyses of 
Table 1 - Breeding traits for a Canchim herd. Number of animals $\left(\mathrm{N}_{\mathrm{i}}\right)$, observations $\left(\mathrm{N}_{\mathrm{obs}}\right)$ and contemporary groups $(C G)$ plus mean and standard deviation (SD) for the following traits: days to first calving without (DFC) and with $\left(\mathrm{DFC}_{\mathrm{P}}\right)$ penalization of non-calving heifers; days to calving without $\left(\mathrm{DC}_{\mathrm{HC}}\right)$ and with $\left(\mathrm{DC}_{\mathrm{PHC}}\right)$ penalization of non-calving cows; scrotal circumference at 12 months of age (SC12); weight of males and females at 12 months of age (W12); weight of heifers at the beginning of the first breeding season (WFBS) and at first calving (WFC); weight of cows at the beginning of the breeding season (WBS) and at calving (WC).

\begin{tabular}{|c|c|c|c|c|}
\hline Traits & $\mathrm{N}_{\mathrm{i}}$ & $\mathrm{N}_{\mathrm{obs}}$ & CG & Mean \pm SD \\
\hline \multicolumn{5}{|l|}{ Males } \\
\hline $\mathrm{SC} 12$ & 1,450 & 1,450 & 107 & $20.96 \pm 3.67 \mathrm{~cm}$ \\
\hline \multicolumn{5}{|c|}{ Males + females } \\
\hline $\mathrm{W} 12$ & 6,326 & 6,326 & 500 & $219.66 \pm 43.97 \mathrm{~kg}$ \\
\hline \multicolumn{5}{|c|}{ Heifers only } \\
\hline $\mathrm{DFC}$ & 1,197 & 1,197 & 166 & $328.30 \pm 38.00$ days \\
\hline $\mathrm{DFC}_{\mathrm{P}}$ & 1,840 & 1,840 & 188 & $348.54 \pm 48.55$ days \\
\hline WFBS & 968 & 968 & - & $344.64 \pm 39.21 \mathrm{~kg}$ \\
\hline WFC & 795 & 795 & 107 & $426.99 \pm 48.37 \mathrm{~kg}$ \\
\hline \multicolumn{5}{|c|}{ Heifers + cows } \\
\hline $\mathrm{DC}_{\mathrm{HC}}$ & 1,602 & 5,403 & 438 & $337.37 \pm 42.76$ days \\
\hline $\mathrm{DC}_{\mathrm{PHC}}$ & 2,073 & 8,736 & 448 & $363.94 \pm 53.86$ days \\
\hline WBS & 1,521 & 4,996 & - & $436.79 \pm 76.48 \mathrm{~kg}$ \\
\hline WC & 1,308 & 4,103 & 164 & $491.94 \pm 70.19 \mathrm{~kg}$ \\
\hline
\end{tabular}

the data showed no age of heifer effect on these traits so the models did not consider this covariate.

Two-trait analyses were used to obtain genetic correlations for the $\mathrm{DC}, \mathrm{DC}_{\mathrm{P}}, \mathrm{DFC}$ and $\mathrm{DFC}_{\mathrm{P}}$ traits with the SC12, W12, WC, WFC, WBS and WFBS traits. Analyses of the $\mathrm{DC}_{\mathrm{P}}$ and $\mathrm{DC}$ data were carried out using a data set which included both cows and heifers $\left(\mathrm{DC}_{\mathrm{PHC}}\right.$ and $\left.\mathrm{DC}_{\mathrm{HC}}\right)$. The models used for the $\mathrm{DC}_{\mathrm{HC}}, \mathrm{DC}_{\mathrm{PHC}}, \mathrm{DFC}$ and $\mathrm{DFC}_{\mathrm{P}}$ data were the same as were used for the one-trait analyses, except that permanent environmental effects were considered only for the $\mathrm{DC}_{\mathrm{PHC}}$ data due to results of the likelihood ratio tests of the one-trait analyses. Models for the analyses of the SC12, W12, WC and WBS data included fixed effects, a covariate and additive direct and permanent environmental random effects, maternal (for the $\mathrm{SC} 12$ and $\mathrm{W} 12$ data) or animal (for the WC and WBS data). For the SC12 data, residual covariance was set to zero because the data records were taken from different animals. Fixed effects and covariates included in the models of each trait were as follows: SC12, contemporary group (year and month of birth), age of the animal (linear effect); W12, contemporary group (sex, year and month of birth), age of cow at calving (linear and quadratic effects); WC, contemporary group (year and month of birth) and physiological state of the female, age of cow at calving (linear and quadratic effects); and WBS, breeding season and physiological state of the female, age of cow at the beginning of the breeding season (linear and quadratic effects).

Classification of the physiological state of the female for the WC and WBS data was the same as for $\mathrm{DC}$ and $\mathrm{DC}_{\mathrm{P}}$ data. For the WFC data models included not only additive direct effects but also contemporary group (year and month of birth) and age of cow at calving (linear effect) fixed effects, while for the WFBS data they included additive direct random effects and breeding season and age of cow at the beginning of the breeding season (linear effect) fixed effects.

\section{Results and Discussion}

A descriptive summary of the traits studied is presented in Table 1. The Canchim SC12 and W12 means in our study agreed with those previously reported for the same Canchim herd (Gianlorenço et al., 2003; Talhari et al., 2003) and the $\mathrm{DC}_{\mathrm{HC}}, \mathrm{DC}_{\mathrm{PHC}}, \mathrm{DFC}$ and $\mathrm{DFC}_{\mathrm{P}}$ means were similar to values reported for Nelore beef cattle (Pereira et al., 2001; Mercadante et al., 2002; Forni and Albuquerque, 2005). Furthermore, the WC mean in our study was similar to that reported for $1 / 2$ Canchim $+1 / 2$ Nelore females (Alencar et al., 1999) and the WBS mean was only a little higher than that reported for Nelore cattle (Mercadante et al., 2004).

Variance components, heritabilities and the portion of the total phenotypic variation due to permanent environment, estimated by the one-trait analyses, for $\mathrm{DC}, \mathrm{DC}_{\mathrm{P}}$, DFC and $\mathrm{DFC}_{\mathrm{P}}$, are presented in Table 2. Our Canchim DFC $\left(h^{2}=0.22 \pm 0.07\right)$ and $\operatorname{DFC}_{P}\left(h^{2}=0.15 \pm 0.05\right)$ heritability estimates were higher than the Nelore date of first calving heritability $\left(\mathrm{h}^{2}=0.11\right)$ obtained by Gressler et al. (2000) and the Nelore DFC and $\mathrm{DFC}_{\mathrm{P}}$ heritability $\left(\mathrm{h}^{2}=0.07\right.$ in both cases) reported by Mercadante et al. (2002). It can be seen that in our study the inclusion of females which did not calve decreased DFC heritability 
Table 2 - Variance components and genetic parameter estimates obtained in one-trait analyses of a Canchim herd. Table shows the following traits: days to first calving without $(\mathrm{DFC})$ and with $\left(\mathrm{DFC}_{\mathrm{P}}\right)$ penalization of non-calving heifers; days to calving without $(\mathrm{DC})$ and with $\left(\mathrm{DC}_{\mathrm{P}}\right)$ penalization of non-calving cows. Additive genetic variance $\left(\sigma_{\mathrm{a}}^{2}\right)$; permanent environmental variance $\left(\sigma_{\mathrm{c}}^{2}\right)$; residual variance $\left(\sigma_{\mathrm{e}}{ }^{2}\right)$; heritability $\left(\mathrm{h}^{2}\right)$; fraction of the variance due to permanent environment $\left(\mathrm{c}^{2}\right)$; and standard error (se). The subscript $\mathrm{C}\left(\mathrm{DC}_{\mathrm{C}}\right.$ and $\left.\mathrm{DC}_{\mathrm{PC}}\right)$ stands for cows only and $\mathrm{HC}\left(\mathrm{DC} \mathrm{HC}_{\mathrm{HC}}\right.$ and $\left.\mathrm{DC} \mathrm{PHC}_{\mathrm{PH}}\right)$ for heifers and cows combined.

\begin{tabular}{|c|c|c|c|c|c|c|c|c|}
\hline \multirow[t]{2}{*}{ Traits } & \multicolumn{3}{|c|}{$\begin{array}{l}\text { Model } 1 \text { (not including permanent } \\
\text { environmental effect) }\end{array}$} & \multicolumn{5}{|c|}{$\begin{array}{l}\text { Model } 2 \text { (including permanent } \\
\text { environmental effect) }\end{array}$} \\
\hline & $\sigma_{a}^{2}$ & $\sigma_{\mathrm{e}}^{2}$ & $\mathrm{~h}^{2} \pm \mathrm{se}$ & $\sigma_{a}^{2}$ & $\sigma_{\mathrm{c}}^{2}$ & $\sigma_{\mathrm{e}}^{2}$ & $h^{2} \pm \mathrm{ep}$ & $\mathrm{c}^{2} \pm \mathrm{se}$ \\
\hline \multicolumn{9}{|c|}{ Heifers only } \\
\hline DFC & 164.1 & 585.0 & $0.22 \pm 0.07$ & - & - & - & - & - \\
\hline $\mathrm{DFC}_{\mathrm{P}}$ & 186.0 & 1065.0 & $0.15 \pm 0.05$ & - & - & - & - & - \\
\hline \multicolumn{9}{|c|}{ Cows only } \\
\hline DCc & 28.3 & 745.8 & $0.04 \pm 0.01$ & 16.7 & 20.5 & 736.0 & $0.02 \pm 0.01$ & $0.03 \pm 0.02$ \\
\hline $\mathrm{DC}_{\mathrm{PC}}$ & 93.6 & 1257.9 & $0.07 \pm 0.01$ & 38.5 & 69.9 & 1235.1 & $0.03 \pm 0.01$ & $0.05 \pm 0.01$ \\
\hline \multicolumn{9}{|c|}{ Heifers + cows } \\
\hline $\mathrm{DC}_{\mathrm{HC}}$ & 39.0 & 741.8 & $0.05 \pm 0.01$ & 32.8 & 9.7 & 737.6 & $0.04 \pm 0.02$ & $0.01 \pm 0.02$ \\
\hline $\mathrm{DC}_{\mathrm{PHC}}$ & 131.0 & 1318.0 & $0.09 \pm 0.01$ & 75.6 & 65.8 & 1297.9 & $0.05 \pm 0.01$ & $0.05 \pm 0.01$ \\
\hline
\end{tabular}

(Table 2), contrasting with the results reported by Mercadante et al. (2002) who found that heritability was the same for both DFC and DFC . Our DFC heritability estimates suggest that this trait presents sufficient genetic variation to respond to selection.

In our analyses of Canchim $\mathrm{DC}$ and $\mathrm{DC}_{\mathrm{P}}$ data the inclusion of permanent environmental effects in the model (model 2) reduced the additive direct component of variance. However, comparison of models 1 and 2 indicated that this effect was significant only for the $\mathrm{DC}_{\mathrm{P}}$ data with cows and heifers $\left(\mathrm{DC}_{\mathrm{PHC}}\right)$ or with cows only $\left(\mathrm{DC}_{\mathrm{PC}}\right)$. This suggests that a large part of the additive genetic variance in model 1 (without permanent environmental effects) was due to non-additive animal effects, with the inclusion of permanent environmental effects in the model (model 2) reducing heritability estimates from $\mathrm{h}^{2}=0.07$ for $\mathrm{DC}_{\mathrm{PC}}$ and $\mathrm{h}^{2}=0.09$ for $\mathrm{DC}_{\mathrm{PHC}}$ in model 1 to $\mathrm{h}^{2}=0.03$ for $\mathrm{DC}_{\mathrm{PC}}$ and $\mathrm{h}^{2}=0.05$ for $\mathrm{DC}_{\mathrm{PHC}}$ in model 2 (Table 2). There were no differences between models for the non-penalized data $\left(\mathrm{DC}_{\mathrm{C}}\right.$ and $\left.\mathrm{DC}_{\mathrm{HC}}\right)$, indicating that the permanent environmental effect for the animal was not an important factor. Our observations are supported by the fact that Pereira et al. (2000) reported that in a two-trait analysis of Nelore cattle there was a decrease in $\mathrm{DC}_{\mathrm{P}}$ heritability from 0.17 to 0.07 .

We also found that the model 1 DC estimated heritability calculated without penalized data, was low at $\mathrm{h}^{2}=0.04$ for cows only and $\mathrm{h}^{2}=0.05$ for heifers plus cows (Table 2) and similar to the lower limit $\left(\mathrm{h}^{2}=0.02\right.$ to $\left.\mathrm{h}^{2}=0.09\right)$ of the heritability estimates reported by Mercadante et al. (2002) and Forni et al. (2003) using models which included permanent environmental effects. Furthermore, our model $2 \mathrm{DC}_{\mathrm{P}}$ heritability estimates using penalized data were also low at $\mathrm{h}^{2}=0.03$ for cows only and $\mathrm{h}^{2}=0.05$ for heifers plus cows (Table 2) and were lower than the $h^{2}=0.07$ to $h^{2}=0.16$ reported by other workers (Meyer et al., 1991; Johnston and Bunter, 1996; Pereira et al.; 2000; Mercadante et al.; 2002). In our herd, the low values of the fraction of variance attributed to permanent environmental effects and of heritabilities indicate the greater influence of the temporary environment on DC and $\mathrm{DC}_{\mathrm{P}}$ values.

We found a small increase in DC heritability estimates when cows which did not calve were included in the cow $\left(\mathrm{DC}_{\mathrm{PC}}\right)$ and cow and heifer $\left(\mathrm{DC}_{\mathrm{PHC}}\right)$ data sets, despite the fact that the magnitude of the standard error suggests that the differences were not significant. However, this increase may have been due to the fact that the data sets which included non-calving females were less selected than the data sets which did not include non-calving females, that is, using only fertile females could mask some trait variability and genetic differences between animals. We also found that with the penalization DFC heritability decreased from $\mathrm{h}^{2}=0.22$ to $\mathrm{h}^{2}=0.15$ (Table 2 ), but due to high standard errors this difference may not be significant. Mercadante et al. (2002) reported that DC heritability increased from $\mathrm{h}^{2}=0.02$ to $\mathrm{h}^{2}=0.12$ with the inclusion of non-calving heifers and cows, although for DFC heritability these workers did not find the effect of inclusion or exclusion of noncalving heifers.

The DFC and $\mathrm{DFC}_{\mathrm{P}}$ heritability coefficients were higher than the corresponding $\mathrm{DC}$ and $\mathrm{DC}_{\mathrm{P}}$ values, indicating higher genetic variability for heifers than for cows. This could be the result of the culling of open cows, changes in genetic or residual variances (or both) or it could be related to differences in the age at which puberty occurred in the heifers, which would obviously be a less important factor for cows. These comments reflect those made by Meacham and Notter (1987). Inclusion of heifers in cows data sets caused non-significant increases in DC heritability, with or without penalized data, probably due to the higher additive genetic variability of the trait DFC. 
Genetic parameter estimates obtained by the two-trait analyses of $\mathrm{DFC}$ and $\mathrm{DFC}_{\mathrm{P}}$ with $\mathrm{SC} 12, \mathrm{~W} 12, \mathrm{WFC}$ and WFBS, and of $\mathrm{DC}_{\mathrm{HC}}$ and $\mathrm{DC}_{\mathrm{PHC}}$ with $\mathrm{SC} 12, \mathrm{~W} 12, \mathrm{WC}$ and WBS, are presented in Table 3. It should be emphasized that permanent environmental random effects were only included in the $\mathrm{DC}_{\mathrm{PHC}}$ model. Heritability estimates of DFC, $\mathrm{DFC}_{\mathrm{P}}, \mathrm{DC}_{\mathrm{HC}}$ and $\mathrm{DC}_{\mathrm{PHC}}$ obtained in the two-trait analyses were in agreement with those estimated in the one-trait analyses. Studies in beef cattle have reported lower heritability estimates for DFC and $\mathrm{DFC}_{\mathrm{P}}$ (Johnston and Bunter, 1996; Forni and Albuquerque, 2005) and similar heritability estimates for DC and $\mathrm{DC}_{\mathrm{P}}$ (Meyer et al., 1991; Johnston and Bunter, 1996; Pereira et al., 2000; Pereira et al., 2001; Forni and Albuquerque, 2005).

Heritabilities estimates of SC12 and W12 (Table 3) were also within the range previously obtained for beef cattle (Meyer et al., 1991; Gressler et al., 2000; Mello et al., 2002; Forni and Albuquerque, 2005). Published studies involving WFC and WFBS are scarce but in our study the heritability estimates obtained for these traits were of medium magnitude, indicating that it is possible to obtain genetic progress for theses traits by selection. We found that the heritability for WBS was $\mathrm{h}^{2}=0.35$ and 0.34 , equal to that reported by Mercadante et al. $(2004)\left(\mathrm{h}^{2}=0.34\right)$ but higher than the $\mathrm{h}^{2}=0.21$ obtained by Meyer et al. (1991) for weight at breeding. Our WC estimated heritability was high (0.52 and 0.51).

We found that the genetic correlations $\left(\mathrm{r}_{\mathrm{g}}\right)$ of $\mathrm{SC} 12$ with DFC $\left(r_{g}=-0.32\right)$ and $\operatorname{DFC}_{P}\left(r_{g}=-0.30\right)$ were favorable, indicating that selection for $\mathrm{SC} 12$ would have a positive effect on female reproductive efficiency. These estimates are higher than the $r_{g}=-0.14$ for Nelore DFC and scrotal circumference at 18 months (SC18) reported by Forni and Albuquerque (2005). In our study the genetic correlations of
$\mathrm{DC}$ and $\mathrm{DC}_{\mathrm{P}}$ with $\mathrm{SC} 12$ were also favorable and within the range of $r_{g}=-0.41$ to $r_{g}=-0.04$ previously reported for the correlation between these female traits and SC18 for Australian beef cattle (Meyer et al., 1991) and for B. indicus Nelore cattle (Pereira et al., 2000). In fact, the genetic correlation between $\mathrm{SC} 12$ and $\mathrm{DC}_{\mathrm{P}}$ reported for Angus cattle by Meyer et al. (1991) was $\mathrm{r}_{\mathrm{g}}=-0.28$, which is similar to the $r_{g}=-0.20$ estimated in this study for the same two traits. The favorable genetic correlations of $\mathrm{SC} 12$ with $\mathrm{DFC}, \mathrm{DFC}_{\mathrm{P}}$, $\mathrm{DC}_{\mathrm{HC}}$ and $\mathrm{DC}_{\mathrm{PHC}}$ show that male $\mathrm{SC} 12$ is a good selection criterion when improvement in female reproductive traits is desired, and may result in genetic gain of both precocity and fertility.

Genetic correlations of $\mathrm{DFC}$ and $\mathrm{DFC}_{\mathrm{P}}$ with $\mathrm{W} 12$ were positive, although of low magnitude (Table 3), indicating that heavier heifers may have lower reproductive performance at first calving. These results agree with those reported by Johnston and Bunter (1996), who observed positive genetic correlation values of $r_{g}=0.08$ and $r_{g}=0.10$ between DFC and body weight. Forni and Albuquerque (2005) found a genetic correlation close to zero $\left(\mathrm{r}_{\mathrm{g}}=-0.02\right)$ between DFC and 18-month weight.

We found that the genetic correlations of $\mathrm{DC}_{\mathrm{HC}}$ and $\mathrm{DC}_{\mathrm{PHC}}$ with $\mathrm{W} 12$ were negative but close to zero, indicating that the traits may be controlled by different sets of genes with additive action. These estimates agree with the value of -0.05 reported by Meyer et al. (1991) for the correlation between $\mathrm{DC}_{\mathrm{P}}$ and $\mathrm{W} 12$ in Angus cattle but differed from the values of 0.74 and -0.36 in B. taurus Hereford and crossbred zebu cattle, also cited by Meyer et al. (1991). Forni and Albuquerque (2005), with Nelore cattle, and Johnston and Bunter (1996), with Angus cattle, estimated genetic correlations of 0.07 for weight at 18 months of age with DC and $\mathrm{DC}_{\mathrm{P}}$

Table 3 - Genetic parameter estimates of days to first calving with $\left(\mathrm{DFC}_{\mathrm{P}}\right)$ and without (DFC) penalization of non-calving heifers and days to calving with $\left(\mathrm{DC}_{\mathrm{PHC}}\right)$ and without $\left(\mathrm{DC}_{\mathrm{HC}}\right)$ penalization of non-calving females with scrotal circumference at 12 months of age (SC12), weight of males and females at 12 months of age (W12), weight of heifers at the beginning of the first breeding season (WFBS) and at first calving (WFC), weight of cows at the beginning of the breeding season (WBS) and at calving (WC), obtained in two-trait analyses, in a Canchim herd. Heritability of trait $1\left(\mathrm{~h}^{2}{ }_{1}\right)$; Heritability of trait $2\left(\mathrm{~h}^{2}\right)$; Genetic correlation between traits 1 and $2\left(\mathrm{r}_{\mathrm{g}}\right)$.

\begin{tabular}{|c|c|c|c|c|c|c|c|c|c|c|c|c|}
\hline \multirow[b]{3}{*}{ Trait 2} & \multicolumn{12}{|c|}{ Trait 1} \\
\hline & \multicolumn{3}{|c|}{ DFC } & \multicolumn{3}{|c|}{$\mathrm{DFC}_{\mathrm{P}}$} & \multicolumn{3}{|c|}{$\mathrm{DC}_{\mathrm{HC}}$} & \multicolumn{3}{|c|}{$\mathrm{DC}_{\mathrm{PHC}}$} \\
\hline & $\mathrm{h}_{1}^{2}$ & $\mathrm{~h}_{2}^{2}$ & $\mathrm{r}_{\mathrm{g}}$ & $\mathrm{h}_{1}^{2}$ & $\mathrm{~h}_{2}^{2}$ & $r_{g}$ & $\mathrm{~h}_{1}^{2}$ & $\mathrm{~h}_{2}^{2}$ & $r_{g}$ & $\mathrm{~h}_{1}^{2}$ & $\mathrm{~h}_{2}^{2}$ & $r_{g}$ \\
\hline \multicolumn{13}{|l|}{ Males } \\
\hline $\mathrm{SC} 12$ & 0.23 & 0.37 & -0.32 & 0.15 & 0.35 & -0.30 & 0.05 & 0.36 & -0.20 & 0.05 & 0.35 & -0.20 \\
\hline \multicolumn{13}{|c|}{ Males + females } \\
\hline $\mathrm{W} 12$ & 0.22 & 0.31 & 0.15 & 0.15 & 0.31 & 0.16 & 0.05 & 0.32 & -0.11 & 0.05 & 0.32 & -0.03 \\
\hline \multicolumn{13}{|c|}{ Heifers only } \\
\hline WFBS & 0.22 & 0.38 & 0.04 & 0.16 & 0.38 & 0.32 & - & - & - & - & - & - \\
\hline WFC & 0.23 & 0.31 & 0.29 & 0.16 & 0.32 & 0.45 & - & - & - & - & - & - \\
\hline \multicolumn{13}{|c|}{ Heifers + cows } \\
\hline WBS & - & - & - & - & - & - & 0.05 & 0.35 & 0.18 & 0.05 & 0.34 & 0.23 \\
\hline WC & - & - & - & - & - & - & 0.05 & 0.52 & 0.16 & 0.05 & 0.51 & 0.29 \\
\hline
\end{tabular}


Genetic correlations of $\mathrm{DFC}$ and $\mathrm{DFC}_{\mathrm{P}}$ with $\mathrm{WFC}$ and WFBS, and of DC and $\mathrm{DC}_{\mathrm{P}}$ with $\mathrm{WC}$ and WBS were not found in literature. Correlations obtained in this study were from low to medium and positive, suggesting that females with genetic potential for greater body weights should need more days to calve and to first calving. There was a tendency to increase these correlations with the inclusion of females which did not calve in the data sets, indicating that these females (penalized in the analyses and considered of lower fertility) were probably the heaviest.

From the estimates of genetic correlations of DFC and $\mathrm{DFC}_{\mathrm{P}}$ with WFC and WFBS, and of $\mathrm{DC}_{\mathrm{HC}}$ and $\mathrm{DC}_{\mathrm{PHC}}$ with WC and WBS, it is possible to infer that heavier females show lower reproductive performance, both at first calving and as adults. According to Dickerson (1978), when nutritional limitations occur, such as those predominating in extensive production systems in tropical regions, smaller individuals should be more precocious, starting reproduction and reaching mature weight faster. These animals would require less nutrients for maintenance than larger animals, and would be more fertile and better adapted to nutritionally stressful conditions (Fitzhugh, 1978).

In summary, our data suggests that it is possible to improve female days to calving and days to first calving by selecting for increase in male scrotal circumference at 12 months of age. Furthermore, selection to increase body weight at 12 months of age does not seem to produce significant correlated responses in days to calving, but may increase days to first calving.

\section{Acknowledgments}

We thank Southeast - Embrapa Cattle for providing the data, the Brazilian agencies CNPq, for financing the study and providing a fellowship to the second author and CAPES for a scholarship to the first author.

\section{References}

Alencar MM, Barbosa PF, Barbosa RT and Vieira RC (1993) Parâmetros genéticos para peso e circunferência escrotal em touros da raça Canchim. Rev Bras Zootec 22:572-583. (Abstract in English).

Alencar MM, Barbosa RT and Novaes AP (1999) Característica produtivas e reprodutivas de fêmeas da raça Nelore e cruzadas 1/2 Canchim + 1/2 Nelore. Rev Bras Zootec 28:960-967. (Abstract in English).

Alencar MM and Bugner M (1986) Estudo de idade ao primeiro parto de vacas da raça Canchim. Rev Bras Zootec 15:151156. (Abstract in English).

Alencar MM, Silva AHG and Barbosa PF (1981) Efeitos da consangüinidade sobre os pesos ao nascimento e à desmama de bezerros da raça Canchim. Rev Bras Zootec 10:151-156. (Abstract in English)

Bergmann JAG, Gressler SL, Pereira CS, Penna VM and Pereira JCC (1998) Avaliação de fatores genéticos e de ambiente sobre algumas características reprodutivas de fêmeas da raça
Nelore em regime de estação de monta restrita. Arq Bras Med Vet Zoot 50:633-645. (Abstract in English).

Boldman KG, Kriese LA, Van Vleck LD and Kachman SD (1993) A Manual for Use of MTDFREML. USDA-ARS, Clay Center, $120 \mathrm{pp}$.

Bourdon RM and Brinks JS (1983) Calving date versus calving interval as a reproductive measure in beef cattle. J Anim Sci 57:1412-1417.

Dickerson GE (1978) Animal size and efficiency: Basic concepts. Anim Prod 27:367-379.

Euclides Filho K (1999) Melhoramento Genético Animal no Brasil: Fundamentos, História e Importância. Embrapa Gado de Corte, Campo Grande, doc. 75, 63 pp.

Fitzhugh HA (1978) Animal size and efficiency, with special reference to the breeding female. Anim Prod 27:393-401.

Forni S and Albuquerque LG (2005) Estimates of genetic correlations between days to calving and reproductive and weight traits in Nelore cattle. J Anim Sci 83:1511-1515.

Forni S, Dias LT and Albuquerque LG (2003) Análise genética da característica dias para o parto em bovinos da raça Nelore. Arch Latinoam Prod Anim 11:143-148. (Abstract in English).

Garnero AV, Lôbo RB, Bezerra LAF and Oliveira HN (2001) Comparação entre alguns critérios de seleção para crescimento na raça Nelore. Rev Bras Zootec 30:714-718. (Abstract in English).

Gressler SL, Bergmann JAG, Pereira CS, Penna VM, Pereira JCC and Gressler MGM (2000) Estudo das associações genéticas entre perímetro escrotal e características reprodutivas de fêmeas Nelore. Rev Bras Zootec 29:427-437. (Abstract in English).

Gianlorenço VK, Alencar MM, Toral FLB, Mello SP, Freitas AR and Barbosa PF (2003) Herdabilidades e correlações genéticas de características de machos e fêmeas, em um rebanho bovino da raça Canchim. Rev Bras Zootec 32:1587-1593. (Abstract in English).

Gunski RJ, Garnero AV, Borjas AR, Bezerra LAF and Lôbo RB (2001) Estimativas de parâmetros genéticos para características incluídas em critérios de seleção em gado Nelore. Cienc Rural 31:603-607. (Abstract in English).

Johnston DJ and Bunter KL (1996) Days to calving in Angus cattle: Genetic and environmental effects, and covariances with other traits. Liv Prod Sci 45:13-22.

Macneil MD and Newman S (1994) Genetic analysis of calving date in Miles City Line 1 Hereford cattle. J Anim Sci 72:3073-3079.

Meacham NS and Notter DR (1987). Heritability estimates for calving date in simental cattle. J Anim Sci 64:701-705.

Meyer K, Hammond K, Mackinnon MJ and Parnell PF (1991) Estimates of covariances between reproduction and growth in Australian beef cattle. J Anim Sci 69:3533-3543.

Mello SP, Alencar MM, Silva LOC, Barbosa RT and Barbosa PF (2002) Estimativas de co(variâncias) e tendências genéticas para pesos em um rebanho Canchim. Rev Bras Zootec 31:1707-1714. (Abstract in English).

Mercadante MEZ, Packer IU, Razook AG, Cyrillo JNSG and Figueiredo LA (2002) Dias ao parto de fêmeas Nelore de um experimento de seleção para crescimento. I - Modelo de repetibilidade. Rev Bras Zootec 31:1715-1725. (Abstract in English). 
Mercadante MEZ, Razook AG, Trovo JBF, Cyrillo JNSG and Figueiredo LA (2004) Parâmetros genéticos do peso no início da estação de monta, considerado indicativo do peso adulto de matrizes Nelore. Rev Bras Zootec 33:1135-1144. (Abstract in English).

Mood AM, Graybill FA and Boes DC (1974) Tests of hypotheses. In: Mood AM, Graybill FA and Boes DC (eds) Introduction to the Theory of Statistics. McGraw-Hill, Tokyo, pp 401470 .

Pereira E, Eler JP and Ferraz JBS (2000) Correlação genética entre perímetro escrotal e algumas características reprodutivas na raça Nelore. Rev Bras Zootec 29:1676-1683. (Abstract in English).

Pereira E, Eler JP and Ferraz JBS (2001). Análise genética de algumas características reprodutivas e suas relações com o desempenho ponderal na raça Nelore. Arq Bras Med Vet Zootec 53:720-727. (Abstract in English).

Randel RD (1990) Nutrition and postpartum rebreeding in cattle. J Anim Sci 68:853-862.

Talhari FM, Alencar MM and Mascioli AS (2003) Correlações genéticas entre características produtivas de fêmeas em um rebanho da raça Canchim. Rev Bras Zootec 32:880-886. (Abstract in English).

Associate Editor: Luiz Lehmann Coutinho 